\title{
POLISH INFLUENCES ON THE BALTIC DÉMARCHES OF ROMANIAN DIPLOMACY.
}

1920-1930

\section{FLORIN ANGHEL \\ Nicolae Iorga Institute of History, Bucharest}

Whenever challenged to take up the subject of Poland and the Baltic States informally, in a private circle, Marshal Józef Piłsudski would always bring into discussion his Lithuanian origin and his attraction to the neighbouring state, which he was inclined to consider a rebellious offspring of the Polish Republic. In one of his Lithuanian tales full of meaning, the Marshal would compare Lithuania with a dear old eccentric aunt: 'When someone opens a window, she will rush out to shut it lest her enemies should fly in; and, when some other person knocks on the door, she will fling it wide open and say to some imaginary interlocutors, "Come in, gentlemen!"' (An allusion was being made here to the uncanny friendship between Lithuania and the Soviets). The 'creator' of modern Poland was so much taken with the Lithuanian issue that he provoked a war in order to conquer Wilno (Vilnius) and his native land, and gave instructions that after death his heart be laid in Rasos cemetery of Wilno, where his mother was buried, as a token of his admiration for "the most beautiful town in the world.'

How proper would it be to speak of a systematic model of common interests, or of the maintenance of independent decisionmaking within the Polish-Romanian alliance in their relations with the Baltic region?

Any attempt to define a novel attitude towards the Baltic region and its new realities should address in the first place the question whether conditions were laid for the achievement of the targeted results. We should note that, on the geostrategic and political background resulting from World War I and confirmed by the peace conferences, Romanian diplomacy, in want of a long-term strategy,

${ }^{1}$ Arhiva Ministerului Afacerilor Externe (henceforth A.M.A.E.), Bucharest (Archive of the Ministry of Foreign Affairs), fond Polonia, vol. 51, p. 60. 
settled for some specific, short-term objectives: the creation of the Petite Entente and of the alliance with Poland (both of which had a defensive character), specific interests in the Balkans and, without any doubt, the establishing of privileged relations with the Western Powers, the decisions of which made a large contribution to outlining the legal status of Greater Romania (France, Great Britain, and Italy). Apart from some immediate interests (concerning Hungary, the Soviets and the Balkans), Romanian diplomats (with some notable exceptions, such as Take Ionescu and Nicolae Titulescu in the twenties) did not involve themselves in establishing functional and active relations in Europe and in its central region. Quite typical in this respect seem to be the comments of Milan Stojadinović, former Minister of Foreign Affairs of Yugoslavia: 'We, parties to the Petite Entente, generally believed that we should see eye to eye with France and Great Britain, once these States had reached an understanding on a given subject. No risks were incurred in doing so'. ${ }^{2}$

In the two inter-war decades, the strategies of Romania and of the Baltic States - Lithuania, Latvia, Estonia, and Finland, whose coming into being was the result of processes similar with the unification of Romania - intersected only accidentally, within a common space of interests (the so-called cordon sanitaire); determinism had marked these 'Versailles creations' by predominantly similar events, reference being made here especially to the secret protocols of the Ribbentrop-Molotov Pact of 23 August 1939.

The Baltic States in their turn narrowed down the scope of their diplomatic actions to regional, unidirectional initiatives, which were meant to preserve the status quo or, in the case of Lithuania, to regain control over Vilnius, more often than not, their governments asked for and secured the active support of the Western States (France and Great Britain for Latvia and Estonia) ${ }^{3}$ and even of the USSR (Lithuania). In the twenties, Romania, which was directly interested in preserving and strengthening security and solidarity within the cordon sanitaire, accepted the suggestions and even interference of Warsaw in her eastern policy and, in some instances, those of Paris.

Quite suggestive in this line of argumentation is the following example: on 13 March, the Polish Minister in Paris, Michał Sokolnicki (a close friend of Marshal Piłsudski), requested that Warsaw should

${ }^{2}$ Milan Vanku. Mica Intelegere si politica externa a Iugoslaviei, Bucuresti, $1979,135$.

${ }^{3}$ On this problem, see Kalervo Hovi. The Baltic Area in British Policy, 19181921, vol. 1, Helsinki, 1980. 
approach Bucharest in an 'energetic' manner, as Romania had been much too hesitant about granting diplomatic recognition to Finland. ${ }^{4}$ Romanian-Finnish collaboration was essential in establishing a system of alliances meant to oppose the military offensive of the Red Army against the Polish territories.

In 1919-1920, acting again on the wish of Poland, Romania ignored the reestablishment of the independence and international legal status of the Baltic Republics; what Poland wanted was absolute priority in Riga, Tallinn and Helsinki, and the establishment of a Baltic Union under her aegis. ${ }^{5}$ Therefore, during the first official Romanian-Latvian contacts made in Helsinki in May 1921, the Polish Minister for Foreign Affairs in Riga in his confidential letter to the Romanian Minister in Helsinki, Dimitrie Plesnilć, criticized the awkwardness and reserve previously shown by Romania. After commending the Romanian Minister's 'good feelings' as far as Latvia was concerned, this Latvian document bluntly reminded the recipient that 'Romania ignored Latvia until November 1920, when Take Ionescu, during a trip to Warsaw, declared to the Latvian Minister in Warsaw that Romania was not a day-dreaming country, that Latvia was unknown in Romania and that, as a consequence, the Romanian people could not understand why they should make war with the Russians if the latter were to attack Latvia' ${ }^{6}$

It was only on 15 February 1921, after the joint Polish-French diplomatic approach (and on the advice of Warsaw and Paris), that Romania recognized Latvia and Estonia. Reactions of gratitude followed from Tallinn, from the Estonian Minister for Foreign Affairs, Anton Piip (1 March 1921), and Riga, from the Latvian Minister of Foreign Affairs, Zigfrids Meierovics (10 March 1921). ${ }^{7}$

That Bucharest was closely following the policy of Warsaw is highly noticeable in the case of Lithuania, where common talks were even initiated concerning a possible military action against Kaunas,

${ }^{4}$ Archiwum Akt Nowych (henceforth A.A.N.), Warszawa, M. S. Z., 5809, p. 2.

${ }^{5}$ Józef Lewandowski. Federalizm. Litwa i Bialorus $w$ polityce obozu belwederskiego (XI.1918-IV.1920). Warszawa, 1962, 203-204; Alfred Bilmanis. A History of Latvia. Princeton, 1951, 340. For recent Romanian viewpoints, see Florin Anghel. O uniune imposibilã: relatiile Poloniei cu statele baltice, 1919-1922 (An Impossible Union: Poland's Relations with Baltic States, 1919-1922). Studii si materiale de istorie moderna. 1998, 93-115.

${ }^{6}$ A.M.A.E., Letonia, 8, p. 39-40; telegram of May 22,1921 from Romanian Legation in Helsinki to the Foreign Ministry.

${ }^{7}$ Idem, 1914, 5, p. 157, 160-162. 
in accordance with the stipulations of the defensive alliance of 3 March 1921 (which exclusively regarded the Soviets). Poland had authored a project of confederation with Lithuania ('The United States of Poland and Lithuania'), which would have unified the fiscal, economic, military and diplomatic policies of the two, while acknowledging Lithuania's right over the Vilnius region. ${ }^{8}$ Impermeable to any such suggestions, the government of Kaunas, through Augustinas Voldemaras, delegate to the League of Nations, was systematically rejecting the ever more insistent rumours (of Polish origin) concerning possible collaboration with Germany against Warsaw. 'Lithuania has no alliances, and her wish for independence is incompatible with any understanding with Germany,' declared Voldemaras in Paris on 8 October $1920 .^{9}$ Between the summer of 1923 and the summer of 1924 , several preliminary contacts were made through the legations in Prague between the Romanian and Lithuanian ministers, with Kaunas insistently asking for the establishment of diplomatic relations. On 25 August 1923, in answer to the telegrams received from Minister D. Hiott in Prague, I. G. Duca was making it known that 'the other day Poland requested that we should not resume our relations with Lithuania for the time being' ${ }^{10}$ Driven to despair by the insistence of Lithuania - Kaunas was hoping that a benevolent attitude on the part of Bucharest would somehow release Polish pressure, - the Romanian Minister for Foreign Affairs, I. G. Duca, consulted with the much experienced diplomat in Warsaw, Alexandru Florescu, in search for a solution, be it partial: 'Lithuania has been asking insistently for the establishment of diplomatic relations for a year now. Given her difficulties with Poland, I have postponed an answer. I think it will be difficult for us not to yield to her request now. On the other hand, we do not wish to offend the Poles' ${ }^{11}$ Duca wanted a query made among the officials in Warsaw, in order to prove that the reasons for which Romania was not recognizing the Lithuanian State were, practically, non-existent. 'Undoubtedly, should the Poles continue to object, we shall act on their wish', added the Romanian Minister for Foreign Affairs. ${ }^{12}$

${ }^{8}$ A.A.N., M. S. Z., mikr. B 2524, sygn. 6103.

${ }^{9}$ Ibidem, mikr. B 2523, sygn. 6102.

${ }^{10}$ A.M.A.E., Lituania, 4, p. 251; telegram 1824 / August 24, 1923 from Romanian Minister in Prague, D. Hiott to Romanian Foreign Minister I. G. Duca.

${ }^{11}$ Ibidem, p. 253; telegram 38111 / July 20, 1924 from I. G. Duca for Romanian Minister in Warsaw, Alexandru Florescu.

${ }^{12}$ Ibidem, p. 254. 
On 24 August 1924, Romania recognized Lithuania officially, ${ }^{13}$ being the last European state to do so, barring Poland.

Romania rallied to Poland unconditionally in rejecting the attribution of the Klaipeda (Memel) port to Lithuania. Three proposals were considered at the Ambassadors' Conference of 1923 concerning the status of this town: keeping the status quo (that is, autonomy), annexation to Lithuania or to the German province of Eastern Prussia. On 15 January 1923, without waiting for an international decision to be reached, the Lithuanian troops occupied Klaipeda. This military solution enjoyed full support and sympathy from Moscow: in November 1922, during the talks between Prime Minister Ernestas Galvanauskas and Georgii Chicherin at Kaunas, a sounding was made of the Soviets on the penetration of Lithuanian troops into Klaipeda. Chicherin assured that Moscow raised no objections; moreover, when the event took place, a displacement of Soviet troops was made towards Minsk in order to prevent a possible intervention by Poland. On 16 Feburary, the Ambassadors' Conference presented the Lithuanian government with an ultimate note; Kaunas was to accept the statute of autonomy of the town immediately and unconditionally, in accordance with the Treaty of Versailles (and with Poland's wishes). Isolated and under threat, Galvanauskas accepted the withdrawal on 13 March 1923. ${ }^{14}$ Klaipeda thus preserved its administrative and financial autonomy, but it transferred all other powers to the government of Kaunas, in accordance with the convention of October $1924 .{ }^{15}$ Undoubtedly, this was one of Poland's most bitter defeats in the Baltic region, in an argument in which Warsaw had relied upon all the logistics at hand (the constant support of Romania included). For this reason, after its diplomatic defeat in the issue of Klaipeda, Bucharest decided upon rethinking its Baltic strategies more thoroughly, independently from Poland's convictions and interests.

The privileged relation and strategic alliance between Bucharest and Warsaw were nevertheless maintained and, after the renewal of 1926, even strengthened. After the recognition of Lithuania, the Romanian minister in Warsaw assured Count

${ }^{13}$ Ladas Natkevičius. Aspect politique et juridique du différénd polonolithuanien, Paris, 1930, 52.

${ }^{14}$ Alfred Erich Senn. The Great Powers, Lithuania and the Vilna Question, Leiden, 1966, 108-112; Andrzej Skrzypek, Kłajpeda jako zagadnienie międzynarodowe (1918-1939). Dzieje Najnowsze, 3, 1971, 57-60; Henryk Dominiczak. Granica wschodnia Rzeczypospolitej Polskiej w latach 1919-1939. Warszawa, 1992.

${ }^{15}$ Andrzej Skrzypek, Kłajpeda, p. 60-62. 
Aleksander Skrzyńsky, the head of Polish diplomacy, that Romania would remain a faithful partner to Poland's policy in the region, especially as, according to the Romanian perception of future developments, 'When either Soviet Russia or Germany, or both, decide to wage a war on Poland's back, they will undoubtedly deny any responsibility and push Lithuania in the forefront'. ${ }^{16}$

Romania was tuning its Baltic policy to that of the Petite Entente, inaugurated by Czechoslovakia in 1921, when the latter had sent envoys to Kaunas, Riga and Tallinn. Nonetheless, while the strong spot of Romanian policy was Riga (and the relations with Latvia), President T. G. Masaryk, in indirect cooperation with Moscow, was preoccupied with consolidating Lithuania's independence and avoiding the peril of 'systematic Polonization' (in fact, a transfer of the Polish-Czechoslovakian conflict of interests from Central Europe), which the social-democrat governments of Kaunas (of mason-socialist orientation, according to Jarosław Galia) ${ }^{17}$ were facing. Nevertheless, the debut of the Romanian-Lithuanian relations was not placed under an auspicious sign: the Baltic Republic welcomed an accredited representative of Romania to its capital, but on no account, 'for reasons of susceptibility', could this representative be the minister of Warsaw. ${ }^{18}$ The question would only be settled by the end of 1929, after the creation of the legation of Riga and the appointment of Mihail Sturdza representative of Romania. The latter, actually the father of Romanian Baltic policy, pointed to the relevance of the Lithuanian capital in obtaining reliable information and establishing profitable contacts vis-à-vis the Soviet sphere; he considered 'ever more regrettable' the absence from Kaunas, where 'our presence, in fact, could only serve the interests of our allies, especially as the major interests, at a certain point in time, may concentrate on the capital of Lithuania'. ${ }^{19}$ It is only after the establishment of diplomatic relations with the USSR, during N. Titulescu's mandate, that Bucharest opened permanent legations in Kaunas, Tallinn and Helsinki (the latter had been closed in 1922).

${ }^{16}$ A.M.A.E., Lituania, 4, p. 255; raport 3358 / August 3, 1924 from Al. Florescu, Warsaw, to I. G. Duca.

${ }^{17}$ Jendrich Dejmek, Nacjonalistyczny przewrót na Litwie w grundniu 1926 roku w oczach Konsula Czechosłowackiego w Kownie. Studia z dziejów Rosji i Europy Środkowo-Wschodniej, t. XXXI, 1996, 159-161.

${ }^{18}$ A.M.A.E., Lituania, 1, p. 51-52; aide-mémoire 'Opening of Diplomatic Relations with Lithuania and Accreditation of Our Minister in Baltic States', November 17,1933 , signed by Vintilă Petala.

${ }^{19}$ Idem, 4, p. 262; February 26, 1933. 
Polish influence, pressure and even interference with Romanian diplomacy in the Baltic and Soviet regions in the twenties were perceived as such by the respective capitals. Among others, Finland's minister to Warsaw, Ehrstroem, was calling to the attention of Vasile Grigorcea that the Baltic and Romanian interests were basically identical vis-à-vis the Soviets and that Bucharest, in its negotiations concerning the prolongation of the alliance of 3 March 1921 should not accept any territorial changes, even if at the advice and under the pressure of Poland and France ${ }^{20}$ Likewise, the Estonian Minister of Defence was sharing his misgivings with Mihail Sturdza, then in Tallinn; according to him, in the teeth of Soviet offensive, only stability, solidarity and cooperation among the states lying between the Baltic Sea and the Black Sea (at the worst, without Poland) could safeguard their independence and integrity. ${ }^{21}$ As is known, on 20 April 1925 an unprecedented trilateral Polish-Romanian-Yugoslav Conference opened on the transit of war materiel and the displacement towards South of the group of defence against the USSR, ${ }^{22}$ given the uncertain position of Lithuania.

The fact that the Romanian border on the Dnestr was hermetically closed, the wish for a source of information on the Soviets other than Warsaw and the intention to penetrate diplomatically one of the most sensitive areas of the cordon sanitaire system determined Alexandru Iacovaky, minister in Warsaw, to launch an unprecedented approach to Latvia. During his visit to Riga, in late February - early March 1925, Iacovaky had a long confidential talk with Zigfrids Meierovics. The Latvian Minister for Foreign Affairs put his mind at ease concerning the persistent rumors about a possible Soviet attack on Bessarabia, and added that 'force is the only argument that Russia understands and, in the present situation, we can only be strong if we stay united'. ${ }^{23}$ (meeting of 28 February 1925). Completely reassured

${ }^{20}$ Ibidem, 1914, 20, p. 189; raport 4908 / December 12, 1925 from Vasile Grigorcea, Warsaw, to I. G. Duca.

${ }^{21}$ Ibidem, Letonia, 1, p. 66-69; raport 75 / February 27, 1931 from Romanian Minister in Riga, Mihail Sturdza, to Romanian Foreign Affairs Minister, G. G. Mironescu.

${ }^{22}$ Wiesław Balcerak. Polityka zagraniczna Polski w dobie Locarna. Wrocław, 1967, 130-130; Anna Garlicka, Polska-Jugosławia, 1919-1939. Studia z dziejów Z. S. S. R. i Europy Środkowej, t. XII, 1976, 102-103. Also, Władysław Stepniak, Działalność dyplomacji polskiej w Królestwie S. H. S. w latach 1919-1922. Studia z dziejów Rosji i Europy Środkowo-Wschodniej, t. XXXI, 1996.

${ }^{23}$ A. M. A. E., Letonia, 8, p. 49-50; raport 2 / March 2, 1925 from Romanian Minister in Warsaw, Alexandru Iacovaky, to I. G. Daca. 
after the talks with 'Beneš of the Baltics' (as Meierovics was known in the States of the Petite Entente), Iacovaky admitted on 3 March 1925 in an interview to Rigas Zinas that 'the Baltic States are little known in Romania because all the information about them came from Russia before the war', and added that Bucharest had 'a strong sympathy and a deep admiration for Latvia'. Concomitantly, the Romanian minister submitted to the judgement of the Latvian general public a concise project for economic cooperation, ${ }^{24}$ while also identifying the Romanian products that could penetrate on the difficult Baltic market: oil, grain, timber, and salt.

Impressed by the interest with which he had been received during his first visit to Riga (Iacovaky presented the accreditation letters to President Janis Cakste on 5 March 1925), the Romanian minister returned there in November 1925. During the audience granted by the Latvian president, the Romanian diplomat raised the question of the relations to the USSR and voiced his reserves concerning the Polish-Lithuanian difference (especially as Warsaw expected Bucharest to act in a joint manner towards the government in Kaunas, the Polish diplomacy linking it grosso modo to the stipulations of the 1921 treaty concerning the joint defensive cooperation vis-à-vis Moscow). Čakste also mentioned confidentially that the frontiers with the Soviets did not seem stable and that 'we should prepare for the day when the independence of our countries will come under threat.' More directly, the Latvian leader expressed the official point of view, according to which 'a Soviet war for the conquest of Bessarabia would greatly influence Latvia's situation' ${ }^{25}$

The efforts to stimulate bilateral trade in the mid-twenties quickly proved inefficient: the distances and the lack of communication means were of great consequence in this respect. The Romanian experts in Warsaw did not give up the idea of an optimal market on which the Romanian trade surplus could be placed; after some talks with Nicolate Lucasiewicz, attaché d'affaires in Warsaw, the Minister for Foreign Affairs, Janis Balodis, was fully convinced that the signing of a commercial treaty and the promotion of a favourable exchange rate of the leu against the lat by the two national banks ${ }^{26}$ (meeting of 28 September 1929) were essential. In 1932 the unilat-

${ }^{24}$ Ibidem, p. 51-52; raport 3 / March 3, 1925 from Al. Iacovaky to I. G. Duca.

${ }^{25}$ Ibidem, p. 67-68; raport 67 / November, 21, 1925 from Al. Iacovaky, Riga,

to I. G. Duca.

${ }^{26}$ Ibidem, p. 80-81; raport 38 / September 28, 1929 from Romanian Chargé d'Affaires in Warsaw, N. Lucasiewicz, to Romanian Foreign Affairs Minister, Alexandru Vaida-Voevod. 
eral denunciation by Riga of the Soviet-Latvian commercial treaty signed in 1927 led to the temporary withdrawal of the Soviet oil trusts from the Latvian market; the indefatigable presence of Mihail Sturdza in Riga paved the way for the opening of an unprecedented and surprising outlet for Romanian oil. Once launched, the relation was not necessarily a success; it amounted exclusively to compensations between Latvian rubber footwear and oil from Valea Prahovei. Exchanges normally exceeded 2 million lats in Latvian exports, with imports amounting to the same sum (which would give us a monthly mean of approximately 200,000 lats in one direction). ${ }^{27}$ In the same period, by the end of the twenties, the Latvian economy (the volume of invested capital) was largely dominated by Germany (18.12 million lats in 1929) and Great Britain (13.33 million lats); Poland, whose finance and industry had not yet recovered completely, showed signs of fatigue and advanced modest figures, comparable with those of Romania, a country not quite interested in the process. Neighbouring Lithuania, for instance, with 1.86 million lats, cut a better figure than the Polish investors (1.5 million lats) $\mathrm{did}^{28}$.

The person who imparted a dynamic motion, quite unprecedented, and who aroused a vivid interest in the Baltic area was Mihail Sturdza. Former minister in Washington, future diplomat in Copenhagen and Minister for Foreign Affairs in September-December 1940, in the Legionary Government, Sturdza remained in Riga for over six years (1929-1935). He was the one to establish the first headquarters of a Romanian legation in the Baltic Republics: in Riga, Valdemaras Street, in the same building in which Switzerland had its diplomatic mission. Sturdza reiterated in his political memoirs the reasons which made him promote with such tenacity and pragmatism the Baltic policy of Romania, precarious and ill-constructed until then. As Romania had not contacts with the Soviets (not even by means of railways or roads), the legation in Riga could remedy a chronicle disadvantage. The Baltic Republics had been part of Imperial Russia and their élites (as well as the administration) were familiar with the state of things in Russia. Moreover, given their frequent diplomatic and economic relations with the Soviets, the Baltic capi-

${ }^{27}$ A.A.N., Ambasada Rzeczypospolitej Polskiej w Bukaresztie, vol. 450, p. 291; A. M. A. E., Letonia, 1, p. 176-177. For a Romanian point of view see, also Florin Anghel, Un model strategic româno-polon: canalul Marea Baltic - Marea Neagra - in perioada interbelica (A Strategic Romanian-Polish Model : The Baltic Sea - Black Sea Canal in the Inter-war Period), Revista Istorica, nr. 7-8, 1996, 584-585.

${ }^{28}$ E. Zolmanis. Latvia Among the Baltic States. Riga, 1931, 35-36. 
tals were important centres for contact, intelligence and interpretation of internal and external events. ${ }^{29}$

Sturdza supported and took a public stand in favour of the Polish concept of a 'Europe Between the Seas' (Międzymorze): while in Riga, in contact with the Baltic milieux, he was calling to attention that, should some countries wish to withdraw from this alliance without a signature (the case of Latvia over disagreements with Estonia), Romania should act firmly and assume her role as a regional power. The diplomat made no secret of the 'extremely reduced limits of our possibilities,' but, given the necessity to consolidate the system of states neighbouring upon the Soviets, 'the intermittent presence of a Romanian representative in Kaunas would prove extremely beneficial'. ${ }^{30}$

Sturdza's projects, matched with a visible evolution towards cordiality in the Romanian-Polish relations (see the award of Polish President Ignacy Mościcki with the Order of Charles I by the Minister for Foreign Affairs G. G. Mironescu in February $1929^{31}$ and Warsaw's mediation for the participation of Romania in the signing of the Litvinov protocol in Moscow on 9 February 192932) had extremely interesting and varied effects. The press of German expression in Germany, Switzerland and Sweden, sensitive to the Lithuanian question, gave credit to the rumors according to which Romania and Poland had signed on 1 October a secret treaty directed against the USSR and Lithuania and prepared during the visit of Marshal Piłsudski to Romania. ${ }^{33}$ The Minister of Lithuania to Berlin declared to Minister N. Petrescu-Comnen that the government in Kaunas had information according to which a secret agreement had been signed during G. G. Mironescu's visit to Warsaw in February 1929. Comnen rated this information 'deceptive' and reminded that, not so long before, Romania had offered to act as an honest courier between Warsaw and Kaunas. ${ }^{34}$

${ }^{29}$ Mihail Sturdza. România şi sfârşitul Europei. Amintiri din tara pierdutć (Romania and the End of Europe. Memoirs from the Lost Country), Alba IuliaParis, 1994, p. 65.

${ }^{30}$ A.M.A.E., Letonia, 1, p. 52-54; raport 90 / March 4, 1930 from Mihail Sturdza, Riga, to G. G. Mironescu.

${ }^{31}$ A.M.A.E., Letonia, 1, p. 52-54; raport 90 / March 4, 1930 from Mihail Sturdza, Riga, to G. G. Mironescu.

${ }^{32}$ See the text in Monitor Oficial, nr. 70, March 27, 1929, p. 2-5.

${ }^{33}$ A.M.A.E., Polonia, 53, p. 180-182.

${ }^{34}$ Ibidem, p. 176; telegram 3968 / March 12, 1929 from Romanian Minister in Berlin, Nicolae Petrescu-Comnen, to Foreign Affairs Ministry. 
No less true was that Bucharest - an adept of the status quo strategy - was disturbed by the attitude of the nationalist Lithuanian Prime Minister Augustinas Voldemaras, who, on 2 April 1928, wrote to the Polish Prime Minister that "not having signed the Versailles Treaty, I do not recognize its validity', ${ }^{35}$ (a thesis sensibly similar with those put forth by Berlin and Moscow). Likewise, in the Government's programme presented in the Seimas on 25 February 1927, the same Voldemaras was rating Poland 'the most dangerous opponent to Lithuania's independence, greater than the Bolsheviks themselves'. ${ }^{36}$ The official press organ Lietuva wrote, in an apocalyptic style, that Poland was nothing but 'a parasite state, a vampire that feeds on other nations' blood' ${ }^{37}$ Romania was also disturbed by the overtly aggressive attitude of Lithuania towards Latvia, the stronghold of her Baltic policy. The Minister for Foreign Affairs, K. Zaunius, admitted on 15 November 1929 that his country did not have many friends because it promoted the 'sacred idea' of regaining Vilna; he accused Latvia of undermining Baltic solidarity (as a result of her close relations with Poland), and added that he 'cannot believe in Latvia's neutrality'. ${ }^{38}$

Concomitantly, an extremely close relationship had developed between Romania and Latvia, in parallel with a necessary strengthening of the Romanian-Polish relations. A détente in Romanian politics was perceived in Riga: President $\breve{C}_{u}$ kste, by way of exception, took the chance to be confidential and critical about Poland in a conversation with the Romanian minister. He showed his discontent for the fact that 'in Poland people work little and spend much', that 'it is a big country, but not a strong one', 'poorly administered' and with an army with great problems. Nonetheless, he assured Warsaw's ally to the South that 'no one can deny here that Poland is the turning table of the situation in Central Europe, and we all understand that we must strengthen our re ations with this country in order to consolidate the defence line which will be eventually opposed to Russia' ${ }^{39}$

Romania tried to silence her suspicions and even to mediate the impasse in the relationship of Warsaw to some of the Baltic capitals, with a clear understanding of the price of solidarity and mutual

${ }^{35}$ A. E. Senn, The Great Powers, p. 211. See, also Robertas Žiugžda. Lithuania and Western Powers, 1917-1940. Vilnius, 1987, 137-144.

${ }^{36}$ E. J. Harrison. Lithuania. London, 1928, 55.

${ }^{37}$ A. E. Senn, The Great Powers, p. 162.

${ }^{38}$ A.M.A.E., Polonia, 50, p. 331-332.

${ }^{39}$ Ibidem, Letonia, 8, p. 67-68. 
cooperation. During the great Polish-Finnish diplomatic conflict of 1927, Bucharest energetically used all means at hand to persuade Helsinki that the signing of a Polish-Soviet non-aggression pact (with which the Romanians were equally dissatisfied) was not tantamount to sowing the seeds of 'division among the Baltic States.' The Romanian mediators managed to settle the situation and the Polish Minister for Foreign Affairs, August Zaleski, eventually confirmed that the rumors had been put about by Moscow ${ }^{40}$ (according to the plan, Lithuania was to gravitate to the Polish sphere of influence, while Latvia, Estonia and Finland to the Soviets).

The eastern and Baltic policy of Romania in the twenties largely relied on the information and abilities of the Polish diplomacy; Poland in her turn requested that her ally integrate into a concerned action which did not always correspond with the basically neutral interests of Romania. Warsaw initiated a policy of prestige, even an exclusive one in the region, often resorting to historical tradition. The idea of a great regional power, which dominated the political and intellectual Polish milieux in the inter-war period, was not in the least the creation of the Minister for Foreign Affairs Józef Beck (19321939). After nine years spent as the French ambassador to Poland (1926-1935), Jules Laroche had come to the conclusion that the Poles wished to demonstrate that they represented a great power in these parts of Europe and that their country "is too powerful to tow the line or rank second in any alliance', ${ }^{41}$

No less true is that the Romanians lacked a well-structured plan by which to offer strong partnerships or take under consideration a number of opportunities. Romanian-Baltic relations confined themselves to good intentions and symbolic cooperation. The longawaited revival was to occur in the following inter-war decade, but the extremely complex international background did not allow for development and evolution in accordance with what initially had been favourable prospects.

${ }^{40}$ Ibidem, Polonia, 1, p. 234; raport 2447 / June 4, 1927 from Al Iacovaky, Warsaw, to Romanian Prime Minister, General Alexandru Averescu.

${ }^{41}$ Documents diplomatiques français. 1932-1939, t. III, Paris, 1967, p. 784785; June 28, 1933. 